\title{
Audit of under-14s who attend sexual health clinics in Gwent, South Wales, UK: identifying young people at risk of abuse and exploitation
}

\section{Louise Cook, Charlotte Fleming}

\begin{abstract}
Background The authors' service has child protection guidance listing locally agreed 'markers' of potential abuse and exploitation to aid identification of vulnerable young people.
\end{abstract}

Objectives To review whether staff are identifying markers of sexual abuse and exploitation, and to review documentation relating to assessment of Fraser criteria in under-14s (young people) attending sexual health clinics in Gwent, South Wales, UK.

Methods Analysis of case notes of 242 young people who made 598 visits to a sexual health clinic between 1 January and 31 December 2003.

Results A total of 81 references to a marker of potential abuse or exploitation were recorded at $8 \%$ of visits and for $11 \%$ of young people. For 72 references a marker was present and for nine was absent. There was no reference to a marker being present or absent for any young males or for $81 \%$ of females. Increasing attendance was associated with increasing prevalence of recorded markers. All young people with three or more markers identified as present were referred onwards compared with $53 \%$ of those with one or two markers present. Referral did not deter future attendance. Reference to Fraser guidance assessment was recorded at $35 \%$ of visits or for $64 \%$ of young people and fully demonstrated at $7 \%$ of visits or for $16 \%$ of young people. There was no recorded assessment for $18 \%$ of females and $60 \%$ of males.

Conclusions The authors' service is not recording sufficient information to help identify young people (particularly males) at risk of abuse or exploitation or to demonstrate the service's compliance with Fraser guidance.

Keywords audit, Fraser competence, sexual abuse, sexual health, young people

J Fam Plann Reprod Health Care 2007; 33(1): 27-30

(Accepted 8 May 2006)

\section{Introduction}

Teenage sex is common, with $34 \%$ of Welsh 15 -year-olds reporting being sexually active (males, 29\%; females, $40 \%) .{ }^{1}$ Age at first sexual experience is declining ${ }^{2}$ and, in Wales, mean age at first intercourse was 14.3 years for both sexes in 2001/2002. ${ }^{1}$ Whilst most teen sex is exploratory, some might be a manifestation of exploitation. Approximately $1 \%$ of children will experience some form of sexual abuse each year, with females more likely to be victims. ${ }^{3}$ Staff are required to identify young people in abusive relationships and refer to social services to protect the child and prevent abuse being perpetrated on anyone else. In Britain, staff providing sexual health advice and treatment to under-16s are also legally obliged to fulfil the Fraser Guidelines (Box 1).

Identifying abuse in young people is difficult. Although a number of risk factors have been identified, there are no clearly validated markers of abuse. ${ }^{3,4}$ There is no consensus on the various definitions of abuse and of the methodology used to collect prevalence data, and findings are often incomplete or conflicting. ${ }^{4}$ As the Victoria Climbié Inquiry highlighted, inadequate communication between different professions, failure to follow agreed protocols, and impaired awareness of child protection issues can all conspire to exploitation being overlooked. 5

Risca Surgery, Risca, Newport, UK

Louise Cook, MRCGP, DFFP, General Practitioner

Sexual and Reproductive Health Directorate, Gwent Healthcare NHS Trust, Cwmbran, UK

Charlotte Fleming, MD, MRCOG, Consultant

Correpondence to: Dr Charlotte Fleming, Sexual and Reproductive Health Directorate, Gwent Healthcare NHS Trust, Llanyrafon House, Llanfrechfa Grange, Cwmbran, Gwent NP44 8YN, UK. E-mail: charlotte.fleming@gwent.wales.nhs.uk

\section{Key message points}

- Fraser competence does not identify young people at risk of sexual exploitation.

- Tools promoting identification of markers of abuse and exploitation need refining.

- A minority of young people present frequently. More work is required to establish whether these young people are at greater risk of sexual exploitation.

Under the Sexual Offences Act 2003,6 all teenagers, including under-13s, are entitled to receive confidential sexual health advice and contraception. More recently, some Area Child Protection Committees in England and Wales have begun issuing protocols requiring mandatory reporting of all sexually active under-13s to police, as well as the collection of data in relation to sexually active under16s. Concern has been expressed that if such guidance is incorporated into new statutory guidance on child protection this will deter young people from seeking help. 7,8

\section{Box 1: Assessment of Fraser criteria}

In order for a client to be deemed Fraser competent the following criteria must be met:

- The client is mature enough to understand the potential risks and benefits of the advice and/or treatment given.

- The client has been encouraged to inform their parents/allow you to inform them of the client's contraceptive needs.

- The client is likely to begin or continue having sexual intercourse with or without contraceptive advice and or treatment.

- The client's physical or mental health or both are likely to suffer unless they receive contraceptive advice and or treatment.

- It is in client's best interests to provide contraceptive advice and or treatment even without parental consent. 
Table 1 Prevalence of information recorded per visit: markers suggestive of exploitation or abuse

\begin{tabular}{|c|c|c|c|}
\hline \multirow{2}{*}{$\begin{array}{l}\text { Markers of potential } \\
\text { exploitation or abuse } \\
\text { (taken from Gwent Sexual } \\
\text { Health Service child } \\
\text { protection guidelines) }\end{array}$} & \multicolumn{3}{|c|}{$\begin{array}{l}\text { Number of visits at which the } \\
\text { following were recorded }(n)\end{array}$} \\
\hline & $\begin{array}{l}\text { Presence } \\
\text { of marker } \\
\text { recorded }\end{array}$ & $\begin{array}{l}\text { Absence } \\
\text { of marker } \\
\text { recorded }\end{array}$ & $\begin{array}{l}\text { No record } \\
\text { of reference } \\
\text { to marker }\end{array}$ \\
\hline $\begin{array}{l}\text { Client depressed/anxious/ } \\
\text { withdrawn }\end{array}$ & 7 & 5 & 586 \\
\hline $\begin{array}{l}\text { Client inappropriately } \\
\text { seductive }\end{array}$ & 1 & 0 & 597 \\
\hline $\begin{array}{l}\text { Signs of physical abuse or } \\
\text { self-harm }\end{array}$ & 5 & 0 & 593 \\
\hline $\begin{array}{l}\text { Repeated attendance for } \\
\text { abdominal pain or vaginal } \\
\text { discharge - no cause found }\end{array}$ & 4 & 0 & 594 \\
\hline Pregnancy or TOP & 5 & 1 & 593 \\
\hline Refusal to discuss injuries & 0 & 0 & 598 \\
\hline Eating disorder & 4 & 0 & 594 \\
\hline Discloses about 'a friend' & 1 & 0 & 597 \\
\hline $\begin{array}{l}\text { Fearful of certain relatives } \\
\text { or friends }\end{array}$ & 2 & 0 & 596 \\
\hline $\begin{array}{l}\text { Not allowed out on dates/ } \\
\text { with friends }\end{array}$ & 1 & 0 & 597 \\
\hline Client has learning disability & 0 & 0 & 598 \\
\hline $\begin{array}{l}\text { Main carera with mental } \\
\text { illness }\end{array}$ & 6 & 0 & 592 \\
\hline Known to social services & 19 & 1 & 578 \\
\hline On the register & 3 & 2 & 593 \\
\hline Client is in care or runaway & 14 & 0 & \\
\hline $\begin{array}{l}\text { Total markers present/ } \\
\text { absent for } 598 \text { visits }(n)\end{array}$ & 72 & 9 & \\
\hline $\begin{array}{l}\text { Visits with reference to a } \\
\text { marker }(n)(n=48)^{\mathrm{b}}\end{array}$ & 45 & 3 & \\
\hline $\begin{array}{l}\text { Individual markers present/ } \\
\text { absent }(n)(n=59)^{\mathrm{c}}\end{array}$ & 50 & 9 & \\
\hline \multicolumn{4}{|c|}{$\begin{array}{l}\text { aThis usually referred to a parent. } \\
\text { bMarkers were noted to be present/absent at a total of } 48 / 598 \\
\text { visits. } \\
\text { c Overall } 22 / 81 \text { of the markers identified were recorded on more } \\
\text { than one occasion at subsequent visits. } \\
\text { TOP, termination of pregnancy. }\end{array}$} \\
\hline
\end{tabular}

\section{Background}

The authors' service has policies in place that outline both the criteria required for a young person to be deemed Fraser competent (Box 1) and of generally agreed markers of abuse (Table 1). This list of markers was initially developed in 2001 with advice from the local child protection team.

In 2003, a multidisciplinary meeting was held to discuss anonymously three cases of vulnerable teenagers with police, social services, community paediatricians and the outreach service. The meeting highlighted that all three teenagers had attended the authors' clinics without staff being fully aware of their vulnerability or high-risk

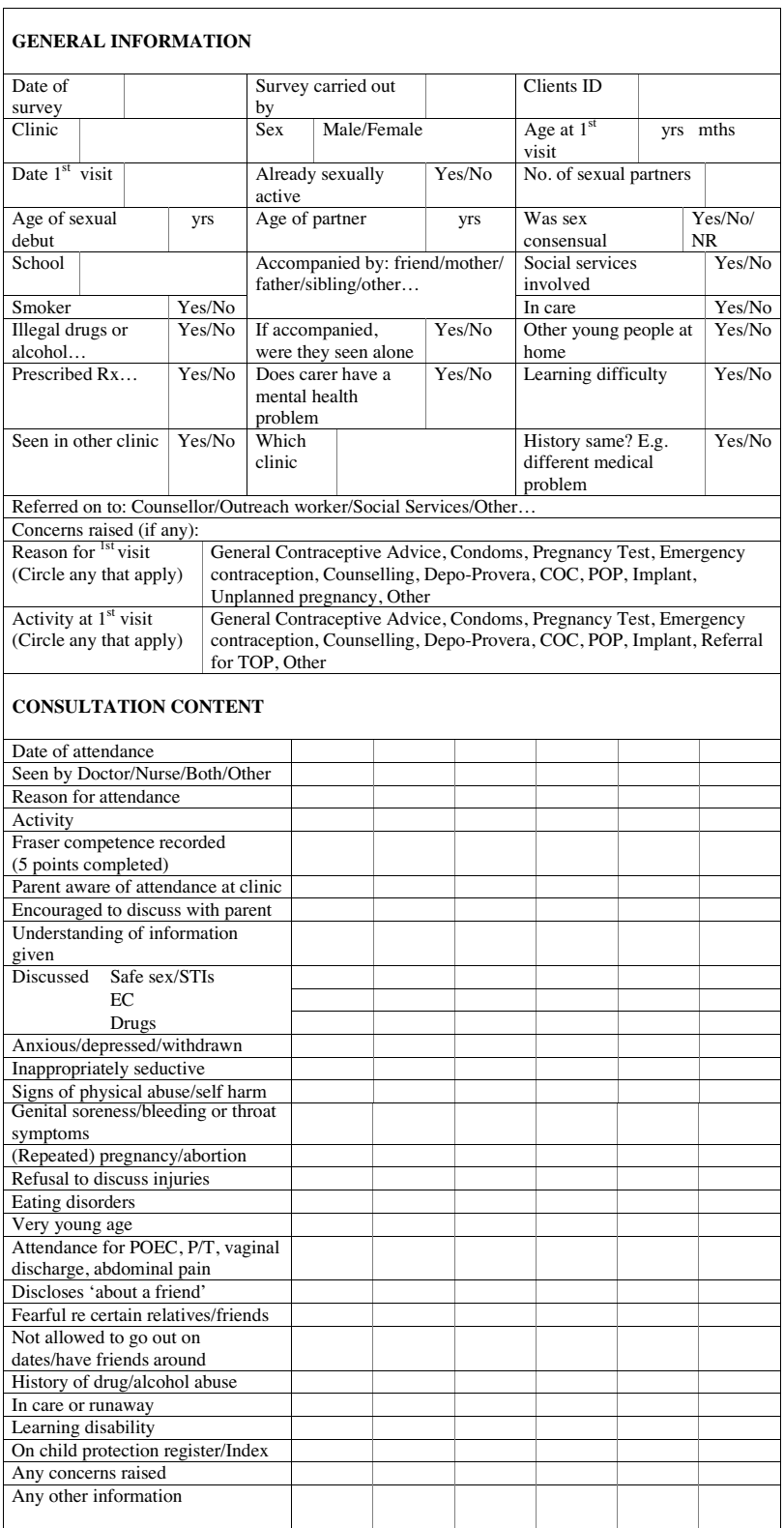

Figure 1 Data collection template used for the audit

lifestyles. Also, information was recorded relating to these young people about which social services were unaware and which might have assisted their management.

It was decided to audit retrospectively how frequently markers of abuse or exploitation and Fraser criteria were recorded in the notes of young clients. First, we believed we might be overlooking cases of exploitation and, second, the service is open to parental criticism if it does not

Table 2 Age of young person at first registration with service and at each visit during 2003

\begin{tabular}{|c|c|c|c|c|c|c|c|c|}
\hline \multirow{3}{*}{$\begin{array}{l}\text { Age } \\
\text { (years) }\end{array}$} & \multicolumn{4}{|c|}{ Age at first registration with service } & \multicolumn{4}{|c|}{ Age at visit during study period } \\
\hline & \multicolumn{2}{|c|}{ Males } & \multicolumn{2}{|c|}{ Females } & \multicolumn{2}{|c|}{ Male visits } & \multicolumn{2}{|c|}{ Female visits } \\
\hline & $n$ & $\%$ & $n$ & $\%$ & $n$ & $\%$ & $n$ & $\%$ \\
\hline$<11$ & 2 & 2 & 3 & 2 & 0 & 0 & 1 & \\
\hline 11 & 10 & 10 & 9 & 6 & 3 & 1 & 7 & 2 \\
\hline 12 & 47 & 47 & 27 & 19 & 85 & 33 & 29 & 8 \\
\hline 13 & 41 & 41 & 103 & 73 & 154 & 61 & 271 & 79 \\
\hline $14^{\mathrm{b}}$ & & & & & 12 & 5 & 36 & 11 \\
\hline Total & 100 & 100 & 142 & 100 & 254 & 100 & 344 & 100 \\
\hline
\end{tabular}

aRefers to first registration with service, which may have taken place prior to or during 2003.

bSome young people who attended during 2003 were seen both before and after their fourteenth birthday. 
Table 3 Young people with one or more markers of potential abuse or exploitation recorded: their age, number of visits made during 2003 and referral details

\begin{tabular}{|c|c|c|c|c|c|c|}
\hline \multirow[t]{2}{*}{ Client code } & \multirow{2}{*}{$\begin{array}{l}\text { Age of client } \\
\text { (years) }\end{array}$} & \multicolumn{2}{|c|}{ Recording of markers } & \multirow{2}{*}{$\begin{array}{l}\text { Visits made per } \\
\text { client during } \\
2003(n)\end{array}$} & \multirow{2}{*}{$\begin{array}{l}\text { Visits at which } \\
\text { marker(s) } \\
\text { recorded }(n)\end{array}$} & \multirow[t]{2}{*}{ Referral } \\
\hline & & Marker present & Marker absent & & & \\
\hline A & $8^{a}$ & 0 & 1 & 1 & 1 & Nil \\
\hline B & 13 & 0 & 1 & 1 & 1 & Nil \\
\hline C & 13 & 1 & 0 & 1 & 1 & ORW \\
\hline D & 12 & 1 & 0 & 1 & 1 & Nil \\
\hline $\mathrm{E}^{\mathrm{b}}$ & 13 & 1 & 0 & 1 & 1 & Nil \\
\hline $\mathrm{F}$ & 13 & 1 & 0 & 1 & 1 & Nil \\
\hline G & 13 & 1 & 0 & 1 & 1 & Nil \\
\hline $\mathrm{H}^{\mathrm{b}}$ & 13 & 1 & 0 & 1 & 1 & Nil \\
\hline I & 13 & 1 & 0 & 1 & 1 & Counsellor \\
\hline J & 13 & 1 & 0 & 1 & 1 & YPC \\
\hline K & 13 & 1 & 2 & 1 & 1 & Nil \\
\hline$L^{b}$ & 13 & 2 & 0 & 1 & 1 & Nil \\
\hline$M$ & 12 & 0 & 1 & 2 & 1 & Nil \\
\hline $\mathrm{N}$ & 12 & 1 & 0 & 2 & 1 & ORW \\
\hline 0 & 13 & 1 & 0 & 2 & 1 & $\mathrm{Nil}$ \\
\hline $\mathrm{Pb}$ & 11 & 1 & 1 & 2 & 1 & YPC \\
\hline $\mathrm{Q}$ & 13 & 1 & 0 & 3 & 1 & TOP \\
\hline $\mathrm{R}$ & 13 & 1 & 2 & 3 & 1 & SS \\
\hline S & 13 & 2 & 0 & 3 & 1 & SS \\
\hline $\mathrm{T}^{\mathrm{b}}$ & 12 & 8 & 0 & 5 & 3 & TOP \\
\hline U & 13 & 2 & 0 & 5 & 2 & TOP $\times 2^{c}$ \\
\hline $\mathrm{V} b$ & 12 & 7 & 0 & 6 & 3 & ORW, SS \\
\hline$W^{b}$ & 13 & 4 & 0 & 6 & 2 & ORW \\
\hline$x$ & 13 & 9 & 0 & 6 & 4 & YPC $\times 2$ \\
\hline $\mathrm{Yb}^{\mathrm{b}}$ & 12 & 3 & 1 & 11 & 4 & ORW, SS, GP \\
\hline$Z^{\mathrm{b}}$ & 13 & 7 & 0 & 15 & 5 & ORW, YPC \\
\hline$A A^{b}$ & 12 & 14 & 0 & 17 & 6 & $\mathrm{ORW} \times 5, \mathrm{SS}$ \\
\hline Total & & 72 & 9 & 100 & 48 & \\
\hline
\end{tabular}

aMother brought daughter to clinic, possibility of abuse considered and excluded.

bSocial services already involved.

cOne pregnancy, two referrals as client failed to attend first appointment with unplanned pregnancy service.

GP, general practitioner; ORW, outreach worker, SS, social services; TOP, termination of pregnancy; YPC, young peoples' clinic.

comply with the Fraser Guidelines. Under-14s were chosen because they fell below the Welsh national average age at first sexual intercourse (14.3 years). ${ }^{1}$

\section{Methods}

All under-14s who attended a clinic between 1 January and 31 December 2003 were identified from the computer database.

The notes of 242 young people (41\% male) and 598 visits (42\% male) were reviewed and a data collection template used to record data items for every visit a young person made during the study period (Figure 1). Details relating to agreed markers of exploitation or abuse were identified in addition to references relating to the assessment of Fraser competence for each visit. These are reported in the present paper. Other details relating to the visit are reported elsewhere. ${ }^{9}$

\section{Results}

The notes of 100 males (254 visits) and 142 females (344 visits) were analysed. Table 2 shows age at first registration with the service and at each visit during 2003 .

Table 4 Assessment of Fraser criteria for each sex

\begin{tabular}{|c|c|c|c|c|}
\hline \multirow{2}{*}{$\begin{array}{l}\text { Fraser criteria } \\
\text { recorded }(n)^{\mathrm{a}}\end{array}$} & \multicolumn{2}{|c|}{ Females } & \multicolumn{2}{|l|}{ Males } \\
\hline & $n$ & $\%$ & $n$ & $\%$ \\
\hline 5 & 34 & 24 & 4 & 4 \\
\hline 3 & 19 & 13 & 2 & 2 \\
\hline 2 & 35 & 25 & 24 & 24 \\
\hline 1 & 28 & 20 & 10 & 10 \\
\hline 0 & 26 & 18 & 60 & 60 \\
\hline Total & 142 & 100 & 100 & 100 \\
\hline
\end{tabular}

aSee Box 1 for details of the five Fraser criteria.
Overall, references to markers of exploitation or abuse were recorded at $48(8 \%)$ visits and for $27(11 \%)$ young people (Table 3 ). There was no reference to a marker being present or absent for $92 \%$ of visits or for $81 \%$ of females and no males ( $89 \%$ of all young people). Where only one or two markers were identified, $53 \%$ of young people were referred onwards. In comparison, a referral was made for all young people in whom three or more markers were present. Each of those individuals referred subsequently revisited the clinic.

Increasing attendance was associated with increasing prevalence of recorded markers (Table 3). Young people who attended more frequently were also more likely to have current social service involvement.

Some reference to the assessment of Fraser criteria (Box 1) was recorded at 209/598 (35\%) visits and for $156 / 242$ (64\%) young people. For $24 \%$ of females and $4 \%$ of males, or at $7 \%$ of total visits, Fraser assessment was explicitly recorded (either by all five points being clearly addressed or by a statement 'Fraser competent' being written in the notes). For a further $58 \%$ of females and $36 \%$ of males between one and three Fraser criteria points were recorded (Table 4). At five visits (all female) the young person did not meet Fraser criteria for the method of contraception requested. There was no recorded assessment of Fraser competence for $26(18 \%)$ females and $60(60 \%)$ males.

\section{Discussion}

We found that we are not recording sufficient information to demonstrate the assessment of Fraser criteria and to identify agreed markers of abuse and exploitation. Our service is of the opinion that staff should assess Fraser competence at each contact with a young person, even when giving advice is the only 
clinical activity. This process should be formally recorded at first contact with a young person and when there is a change in contraceptive method used requiring a higher level of competence. We are therefore falling short of our $100 \%$ standard.

Based on national estimates of abuse it is likely that we are missing cases, particularly as we failed to identify any markers for young males. As important negative findings were rarely recorded we have no way of knowing just how many of the $89 \%$ of young people for whom no markers were noted could be at risk.

Time constraints make it impractical to record everything that is discussed during a consultation. Staff must, however, demonstrate transparency in their work as well as their adherence to the legal framework and national and professional standards laid down for sexual health services. ${ }^{10,11}$ Our service uses proforma sheets for hormonal and intrauterine methods of contraception. These include a section for recording compliance with Fraser guidance. However, it was found that this section was not always being completed. Proformas are not used for barrier methods of contraception and Fraser assessment has to be handwritten in case notes. This might account for why so few males had these details recorded. Other factors that might affect data recording include a reluctance of staff to question young people about very personal matters, a possible fear of having to manage a problem if one arises, and also the fact that young people themselves may be reticent about discussing their relationships. In order to help build trust and encourage a young person to return to clinic it is possible that some sensitive questions might be left to be asked at a follow-up visit. However, in the present study little new information was recorded at subsequent visits for either sex, with the exception of the frequent attendees.

Multiple attendances may be a sign of vulnerability and increasing attendance was associated with an increasing number of markers being recorded for females (Table 3). It is not possible to determine retrospectively if this is because these young people are more vulnerable or whether increasing attendance encourages the development of trust and rapport between a young person and health professional with improved exchange of sensitive information. Either way, although abuse and exploitation may occur more frequently in females, it is likely that we are missing important findings for males. It was also apparent that multiple attendees often visit clinics at different sites. Without an electronic record available to all, clinic staff may be unaware of the full sexual history of a potentially vulnerable young person.

These results have been shared across the service and have assisted the identification of training requirements. We have also developed a proforma sheet for under-16s, similar to that available from the British Association for Sexual Health and HIV. ${ }^{12}$ We are presently piloting its use. We aim to complete the audit cycle 1 year after the proforma has been fully implemented. We anticipate that its use will increase the identification of children involved in risky behaviour and abuse as found by others. ${ }^{13}$ The proforma has been published elsewhere. ${ }^{9}$

\section{Conclusions}

Based on national estimates of abuse it is likely that we are missing many cases. We rarely document Fraser competence fully and we rarely record information that would help identify young people (particularly males) at risk of sexual exploitation or abuse. More work is required to refine and validate tools for the identification of sexual abuse.

We are introducing a gender-neutral history sheet for all under-16s that includes a section for assessing Fraser criteria. This will be combined with a checklist of markers of exploitation, which it is anticipated will be completed over a series of visits as we gain the young person's confidence. A Care Pathway will be used to aid management of those identified as 'at risk'.

A consultant now reviews the notes of all under-14s and the service is also to hold regular multidisciplinary meetings to discuss 'worrying' young people anonymously.

Statements on funding and competing interests

Funding None identified.

Competing interests None identified.

References

1 Health Behaviour in School-aged Children (HBSC) Survey. HBCS Briefing Series: 3. Sexual Health. http://www.cmo.wales.gov.uk /content/work/schools/hbsc3e.pdf. [Accessed 19 October 2005].

2 Wellings K, Nanchahal K, Macdowall W, McManus S, Erens B, Mercer $\mathrm{CH}$, et al. Sexual behaviour in Britain: early heterosexual experience. Lancet 2001; 358: 1843-1850.

3 Kellogg N; the Committee on Child Abuse and Neglect. The evaluation of sexual abuse in children. Paediatrics 2005; 116: 506-512.

4 Cawson P, Wattam C, Brooker S, Graham, K. NSPCC inform. Child Maltreatment in the United Kingdom: A Study of the Prevalence of Abuse and Neglect. November 2000. http://www.nspcc.org.uk/inform [Accessed 24 August 2005].

5 Lord Laming. The Victoria Climbié Inquiry. January 2003. http://www.victoria-climbie-inquiry.org.uk/finreport/finreport.htm [Accessed 14 November 2005].

6 Sexual Offences Act 2003. London, UK: HMSO, 2003. http://www.opsi.gov.uk/ACTS/acts2003/20030042.htm [Accessed 18 December 2005].

7 Bastable R, Sheather J. Mandatory reporting to the police of all sexually active under-13s. BMJ 2005; 331: 918-919.

8 Confidentiality of Adolescent Sexual Health Services: Joint Statement (October 2005). http://www.ffprhc.org.uk/admin/ uploads/FinalSignedDJTStatement.pdf [Accessed 28 January 2006].

9 Cook L, Fleming C. Analysis of clinic attendances of under-14s to sexual health clinics in Gwent, South Wales, UK. J Fam Plann Reprod Health Care 2007; 33: 23-26.

10 The National Assembly for Wales. A Strategic Framework for Promoting Sexual Health in Wales. January 2000. http://www.cmo.wales.gov.uk/content/work/sexualhealth/sexua I-health-strat-e.pdf [Accessed 14 November 2005].

11 Faculty of Family Planning and Reproductive Health Care of the Royal College of Obstetricians and Gynaecologists. Service Standards for Sexual Health Services. January 2006. http://www.ffprhc.org.uk/admin/uploads/ServiceStandards SexualHealthServices.pdf [Accessed 18 February 2006].

12 Thomas A, Forster G, Robinson A. National Guideline on the Management of Suspected Sexually Transmitted Infections in Children and Young People. http://www.bashh.org/guidelines/ 2002/adolescent_final_0903.pdf [Accessed 18 February 2006].

13 Holkar S, Rogstad KE. Introduction of a proforma in the management of under age attendees at a genitourinary clinic. Int J STD AIDS 2005; 16: 278-280.

\section{JOURNAL ONLINE SUBMISSION AND PEER REVIEW}

The Journal now uses an online manuscript submission and peer review system. This can be accessed at http://jfprhc.allentrack.net and authors are encouraged to use the system, which will allow the most efficient processing of their paper. Notes for contributors/guidelines for manuscript submission can also be found on this website. 